\title{
The Polygamy Rules of CD IV:20-V:2 and 11Q19 LVII:15-19 and Their Sources: Implications for Divorce and Remarriage
}

\subsection{Introduction}

Two principal questions arise from the studying of three particular Qumran texts in which the prohibition of polygamy appears: Does polygamy pollute the Temple? Does the prohibition on polygamy also prohibit divorce and remarriage thereafter? In 11 Q19 (11QTemple ${ }^{a}$ ) LVII:15-19 we read: "And he shall not take a wife from all the daughters of the nations, but from his father's house he shall take unto himself a wife, from the family of his father. And he shall not take upon her another wife, for unto himself another (wife) from the house of his father, from his family" (translation by Y. Yadin). In CD IV:20-V:1 we read: "they are caught in two: fornication, by taking two wives בחייהם in their lifetimes, although the principle of creation is 'male and female He created them' and those who went into the ark 'went into the ark two by two.' Concerning the Leader it is written 'he shall not multiply wives to himself." And in CD V:6-12 we read: "They also מטמאים defile the sanctuary, אין הם מבדיל for they do not separate clean from unclean according to the Law, and lie with a woman during her menstrual period. Furthermore they marry each man the daughter of his brothers and the daughter of his sister, vac although Moses said, 'Unto the sister of your mother you shall not draw near; she is the flesh of your mother'" (cf. Lev 18:13). But the law of consanguinity is written for males and females alike, so if the brother's daughter uncovers the nakedness of the brother of her father, she is the flesh (of her father). vac Also they have טמאו corrupted their holy spirit, and with blasphemous language they have reviled the statutes of God's covenant, saying, 'They are not well-founded'” (both translations by E. Cook). ${ }^{1}$

These texts are commonly interpreted as prohibiting both polygamy ${ }^{2}$ and marriage between a man and his niece, but other interpretations have also been offered, such as a prohibition on divorce and on remarriage after

1 DSSEL.

2 See Géza Vermes, "Sectarian Matrimonial Halakhah in the Damascus Rule," JJS 25 (1974): 197-202. Tom Holmén, "Divorce in CD 4:20-5:2 and 11QT 57:17-18: Some remarks on the 
divorce, ${ }^{3}$ because of the apparent oddity of the term בחייהם in CD IV:21. The phrase "they are caught in two: בזנות fornication"4 in CD IV:20 has similarly raised scholarly debates as to whether it relates to two nets, or to two types of illicit sexual relations, ${ }^{5}$ or, as it seems to Schremer, to three "nets." ${ }^{6}$ The prohibition of polygamy in CD IV:20-V:1 seems to have been deduced from the texts of Gen 1:27 (the creation of one man and one woman) and Gen 7:9 (the subsistence of each species is ensured by one male and one female) and from the indirect evidence of a particular interpretation of Deut 17:17 (which prohibits the king to take multiple wives). Gruber, in contrast, contends that Lev 18:18 should be interpreted as: "Do not marry אשה אל אחתה a woman with her fellow woman, בחייה while your wife is living," conflicting with the common interpretation which refers to a prohibition to marry two biological בחייה sisters at the same time. He came to this conclusion because the word in this verse is similar to בחייהם, used in the CD text. ${ }^{7}$

In this chapter I propose an interpretation of the phrase "they are caught in two," justifying the author's intent of two prohibitions; I then dispute Gruber's theory as to the source of the CD's prohibition of polygamy. Finally, I argue that the lemma of the CD relates exclusively to the prohibition of polygamy, and does not address the issue of divorce. ${ }^{8}$

Pertinence of the Question," RevQ 18 (1998): 397-408, at 398 writes: "No one has doubted that the texts apply to the issue of polygamy."

3 Adiel Schremer, "Qumran Polemic on Marital Law: CD 4:20-5:11 and Its Social Background," in Damascus Document: A Centennial of Discovery; Proceedings of the Third International Symposium of the Orion Center for the Study of the Dead Sea Scrolls and Associated Literature, 4-8 February 1998 (ed. Joseph M. Baumgarten et al.; Leiden: Brill, 200o), 147-60, at 148-49 offers an extended list of the different scholarly interpretations of this lemma.

4 This is the common translation of but, as I will demonstrate later in the study, the term has a variety of meanings.

5 William Loader, Philo, Josephus and the Testaments on Sexuality: Attitudes towards Sexuality in the Writings of Philo and Josephus and in the Testaments of the Twelve Patriarchs (Grand Rapids, MI: Eerdmans, 2011), 110-13, deliberates at length on the various possible interpretations and proffers his solution to the phrase by referring to two nets: by taking two wives, a man effects both a sexual misdeed and an act of greed (by becoming richer with the receipt of two dowries).

6 Schremer, "Qumran Polemic," 149-52.

7 Mayer I. Gruber, "Women in the Religious System of Qumran," in Judaism in Late Antiquity (ed. Alan J. Avery Peck et al.; Leiden: Brill, 2001), 173-96.

8 See also Vermes, "Sectarian Matrimonial” and Schremer, “Qumran Polemic," 157-6o. 


\subsection{The Interpretation of CD IV:20-V:1: Disputing Schremer's Theory}

Schremer interprets the text of $\mathrm{CD}$ IV:20-V:1 as relating to three accusations: First, taking two wives; second, defiling the sanctuary (by lying with a menstruating woman); and, third, marrying one's niece. Hence, there are three nets, not two, as the author claims. In his translation of the lemma, Schremer inserts a full stop after each sentence: "And they also pollute the sanctuary by not separating according to the Torah. And they lay with a woman who sees blood of flowing. And they marry each one his brother's daughter or sister's daughter." Thus, he seems to be distinguishing between polluting the sanctuary and lying with a menstruating woman, although, in the original text, אשר אין מש משר הם מבדיל (CD V:6-7). Cook correctly translates as follows: "They also defile the sanctuary, for they do not separate clean from unclean according to the Law, and lie with a woman during her menstrual period." Schremer's punctuation suggests four evil deeds: the three named in CD V:6-7 and a fourth involving taking two wives in CD IV:20-21, which conflicts with his assertion, noted above, that there are three sins. Moreover, when the sentence about the pollution of the sanctuary is divided from the succeeding clauses, we have no clue as to what the phrase "not separating according to the Torah" means (i.e., to what type of separation the author refers); we must therefore assume that the pollution of the sanctuary is related to lying with a menstruating woman, despite Schremer's division of the sentences. Further, he argues that "as the texts stands before us now," the misdeed of marrying one's niece is preceded by the accusation of defiling the Sanctuary, and in his opinion this is incorrect, since the defilement should refer to the marriage with two women that precedes it, not to the marriage with one's niece that follows it (an act that does not defile the Sanctuary, according to his opinion). He justifies this assumption

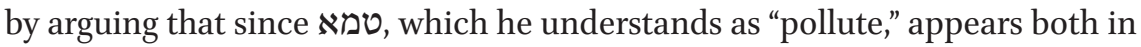
V:6 (וגם מטמאים את המקדש) and in V:11: (וגם את רוח קדשיהם טמאו), "one naturally assumes that they are related to one another." Therefore, the accusation of polluting the Temple should precede the sin of taking two wives, not the sin of marriage with a niece, which does not pollute the Temple. Schremer consequently proposes that we should "remove [the defilement of the sanctuary] from the text altogether" or "relocate it after the accusation of marriage with one's niece and before the accusation of defiling the holy spirit, where it is expected." ${ }^{\prime}$

9 Cook's translation, DSSEL, 151. 
I dispute Schremer's interpretation and the resulting proposal, which are based, inter alia, on the assumption that טמא has always the same meaning; this assumption does not correspond with the facts, as is evident from the varied uses of טמא in Scripture, which are not comparable in their essence and implications. I discuss this issue at length in an Appendix to Chapter 8; here, I will confine myself to observing, for example, the difference in meaning between טמא in Lev 11:44, indicating a defilement of the soul by eating ritually detestable creatures; in Num 19:11, a seven-day unclean period for touching a carcass; in Num 5:13, the impurity of a married woman who has committed adultery; in Num 35:34, the defilement of the land by shedding blood; and in Lev 20:3, the pollution of the Temple by practising idolatry.

Moreover, the two instances טמא in our lemma are not comparable because they explicitly relate to distinct types of pollution of different elements through different misdeeds: the first refers to polluting the Temple by lying with a menstruating woman or by marrying one's niece, whereas the second refers to polluting (corruption, in Cook's translation) their holy spirit by using blasphemous language. ${ }^{10}$

I propose that we read the conjunction וגם as a correlative conjunction meaning not only ... but also — that is, they are caught in two misdemeanours: (1) in the act of fornication, by taking two wives; and (2) in the act of polluting the Temple by lying with menstruating women and by marrying a niece, two transgressions that pollute the Temple. That is, polygamy is perceived as an evil deed, but it does not pollute the Temple. The pollution of the Temple, like the pollution of the land, is not necessarily associated with the concrete entrance into the Temple of a polluted person. The text associates the pollution with failing to separate clean from unclean, according to the correct Torah law, ${ }^{11}$

10 Schremer does not clarify the nature of the sin that pollutes the Temple, that is, whether it relates to the entrance into the Temple of an impure man who has slept with a menstruate or whether it is an abstract type of pollution - the very act of lying with a menstruatesimilar to idolatry that pollutes the Temple (Lev 20:3) or the idolaters (Lev 19:31), or to the woman who practises bestiality (Lev 18:23). Since Schremer does not distinguish between the different types of טומאה "pollution" and does not envisage an abstract type, I assume that, in his opinion, the CD author refers to the concrete pollution of the Temple by a man entering it in a state of impurity after lying with a menstruate. Therefore, he does not conceive that marrying a niece pollutes the Temple. Such an interpretation conflicts with the text, which does not mention entering the Temple but refers exclusively to failing to perform separation and to lying with a menstruate.

11 In Paul Heger, "Celibacy in Qumran-Hellenistic Fiction or Reality? Qumran's Attitude towards Sex" in RevQ. 101 (2013) 53-90, at 81, I have hypothesized that Qumran may have practised a more stringent rule about the duration of impurity of the menstruating 
namely a menstruating woman, and with marrying a niece, not with entering the Temple while unclean. Such pollution may be indirect, occurring through misdeeds, similar to the pollution of the land by spilling innocent blood (Num 35:33-34) or by failing to bury the hanged on the same day (Deut 21:23). ${ }^{12}$ I doubt whether we have the expertise to decide that marrying two wives pollutes the Temple yet marrying one's niece does not, as Schremer seems to argue. Are we qualified to understand why cleansing the pollution resulting from touching a corpse requires sprinkling with water mixed with the ashes of the Red Heifer, whereas other types of pollution, such as leprosy (Lev 14:4-7), require sprinkling with another substance? Or why a man who has lain with a menstruating woman is impure for seven days but then becomes pure again, without even the requirement of a ritual bath (Lev 15:24), yet if he only touches her bed, he is impure for one day but must bathe and wash his clothes (Lev 15:23)? Similarly, we do not understand why shedding innocent blood pollutes the Temple, eating unclean insects pollutes the souls of the consumers, and some sexual misdeeds pollute the land (Lev 18:27). Therefore, Schremer's assumption that marrying two women pollutes the Temple, but marrying one's niece does not, has no foundation. One could conceive the opposite: whilst marrying one's niece is perceived an incest relation, ${ }^{13}$ the marriage of two women is just an unethical deed, by virtue of acting contrary to the divine creation principle. Because we do not know what differentiates those transgressions which pollute the Temple from those that do not, we can understand the intent of the author of the CD lemma, who describes two of the three nets assumed to be hinted at in Isa 24:18: marrying two women is a form of a "sexual misdeed"14

woman, similar to that established by the later rabbis, whereas it is possible that the Pharisees did not practise a strengthened rule. This would explain Qumran's accusation that their opponents transgressed the Torah rules, as they understood it, since it seems incomprehensible that the Pharisees, Qumran's opponents, would not obey the biblical restrictions of sexual intercourse during the woman's menstruation period of seven days.

12 It seems to me that Martha Himmelfarb, "Sexual Relations and Purity in the Temple Scroll and the Book of Jubilees," $D S D$ 6, 1 (1999) $11-36$ at $24-25$, is of the same opinion. She writes: "the Temple Scroll saw the forbidden sexual relationships as producing impurity of the kind that threatened the sanctuary. In matters having to do with sexual relations, the Temple Scroll understands impurity much as $\mathrm{P}$ does, as the result of certain physical processes." We encounter a similar abstract pollution of the Temple by evil deeds in The Testament of Moses 5:2-3: "They shall turn aside from righteousness and approach iniquity, and they shall defile with pollutions the house of their worship."

13 Comparing the prohibition to marry a niece to the biblical prohibition of marrying one's aunt (Lev 18:13) classifies it as incest, similar to the other prohibitions in Lev 18.

See discussion below about the general meaning of the term ther than fornication. 
which does not pollute the Temple, while lying with a menstruating woman and marrying a niece do pollute it. The author then mentions another type of pollution, that of the holy spirit, which occurs through the use of blasphemous language against the statutes of God's covenant.

In conclusion, I propose to understand the lemma as follows: they are caught in two misdemeanours: (1) in the act of fornication, by taking two wives; and (2) in the act of polluting the Temple by lying with a menstruating woman and by marrying a niece, two transgressions that pollute the Temple; polygamy is perceived a sexual misdemeanour, but does not pollute the Temple.

\subsection{Motivations and Sources of the Prohibition on Polygamy in CD}

\subsubsection{The Motivation for the Prohibition: Wassen's Conjecture}

Wassen suggests that the prohibition of polygamy may have been welcomed by "the women in the community" because of tensions between co-wives, alluding to biblical stories that "illustrate such hostility within families with several wives." ${ }^{15}$ We do not know, however, whether this or some other practical motive led Qumran scholars to "reinterpret" the biblical law accordingly, as Wassen alleges, ${ }^{16}$ or whether their decision was based on their genuine interpretation of the biblical relevant text. Based on my studies of Qumran's interpretive system, I would not suggest that Qumran scholars would have "reinterpreted" some biblical rule to suit their practical considerations. ${ }^{17} \mathrm{We}$ should therefore attempt to reveal the biblical source and interpretation that may have led them to prohibit polygamy even though, as it seems to us, there is no such prohibition in Scripture. Careful scrutiny of the relevant $C D$ text is the most appropriate way to begin our investigation.

15 Wassen, Women, 128. I wonder why she refers to the events narrated in Gen 16:4-6 (erroneously identified as Gen 16:29-30 at 128 n. 66), which describe the tension between a maid servant and her mistress when the maid servant becomes the master's surrogate wife and the bearer of his child (vv. 4-5), rather than Laban's pronunciation in Gen 31:50, which refers precisely to the mistreatment of a wife, when her husband marries an additional one. Moreover, in the dialogues that follow between Sarai and Abraham and the angel and Hagar, the latter is never given the title of wife; she is called maidservant, and the abusive relations between a wife and her maidservant who displaces her are vividly portrayed in Prov 30:21-23, thus demonstrating the peculiar character of the Hagar narrative, which therefore cannot serve as a general model of behaviour at polygamous marriage.

16 Ibid.

17 See Heger, Challenges, 21-26 for an extended study concerning this particular topic. 


\subsubsection{The Biblical Source of the Polygamy Prohibition in the CD \\ 6.3.2.1 Lev 18:18 or a Logical Consideration of Gen 1:27 and 7:9?}

We read in CD IV:20-21 the accusation that the author's opponents take "two בחייהם in their lifetime"; the author therefore contends that polygamy is prohibited as long as both women are living. The use of the masculine form בחייהם has produced interpretive difficulties, since one would expect the feminine form (meaning "during the women's lives") — that is, as long as a man's wife lives, he cannot marry another woman, but he may do so after her death. ${ }^{18}$ The issue has become even more complicated because some scholars בחייה have associated this rule with the decree in Lev 18:18, simply because in Lev 18:18 is similar to בחייהם in the CD text. An array of diverging scholarly explanations for this apparent irregularity have been advanced, including a proposal to emend the masculine בחייהם and, as a consequence, to deduce from this verse the prohibitions on polygamy in cases of divorce - that is, that a divorced person cannot remarry as long as his or her former spouse is living.

It seems to me, however, that a conjecture that the $\mathrm{CD}$ author based his prohibition of polygamy on Lev 18:18 because of his use of בחייהם is not justifiable; in both texts, these similar terms are an essential element of the rules, which apply only during the lifetimes of the persons concerned; the similarity therefore does not serve as evidence that Lev 18:18 is the source of the CD's prohibition of polygamy.

Whereas the rabbis and most translators and commentators, including the LXX, understood אחתה in Lev 18:18 as relating to a real sister, and thus as forbidding marriage with two sisters during their lifetimes, ${ }^{19}$ Ginzberg infers by a complex argument that the CD author does not interpret ואשה אל אחתה of Lev 18:18 literally, but in "the sense of 'a wife together with another one," thus forbidding polygamy. ${ }^{20}$ Gruber, however, claims not only that the CD interprets

18 Nevertheless, a number of scholars interpret the term בחייהם as referring to women's lives, or to both, explaining the oddity as a grammatical possibility used in biblical and mishnaic Hebrew, or by proposing an emendation. For a list of relevant scholars, and their various interpretations on this topic, see Vermes, "Sectarian Matrimonial," 400, Wassen, Women, 114-18 and David Instone-Brewer, Divorce and Remarriage in the Bible, The Social and Literary Context (Grand Rapids, MI: Eerdmans, 2002), 62-72.

19 See $b$. Yeb. $8 \mathrm{~b}$.

20 Louis Ginzberg, An Unknown Jewish Sect (New York: Jewish Theological Seminary of America, 1976), at 19 argues that the CD cannot interpret the "sister" literally, because CD equated man and woman regarding sexual restrictions, as we see regarding the prohibition of marrying a niece, identical to the prohibition of a man marrying his aunt (CD V:9-10). Consequently, he assumes the CD author determined that a woman may not marry her brother-in-law after her sister's death, just as a man may not marry his sister-in- 
Lev 18:18 as relating to a metaphorical sister, that is, a fellow woman, but also that this is the simple, real, and only intent of the biblical decree, and the basis of the CD's prohibition of polygamy. ${ }^{21}$ Gruber attempts to demonstrate that Scripture prohibits polygamy and that its abrogation was instituted by the Pharisees, the forerunners of the rabbis, ${ }^{22}$ who justified it by a deliberately biased interpretation of the scriptural rule, to the detriment of the women's legal status. He therefore argues that the phrase אשה אל אחתה in Lev 18:18 must be interpreted as referring to another woman, not to a real sister-like the similar phrase in Exod 26:3, referring to clipping one curtain to another, or the masculine phrase in Exod 25:20 referring to the cherubim facing איש אל אחיו "one to another"; hence, he declares that Lev 18:18 explicitly and clearly prohibits polygamy.

Gruber ignores the fact that the primary meanings of אחות are "brother, sister and kinsfolk," 23 and only by extension do they express the generic concept of two close and similar elements. ${ }^{24}$ Moreover, in the parallel 4Q524 (4QTemple $\left.{ }^{\mathrm{b}}\right)$ 15-22:6, as reconstructed by Émile Puech: "No man may marry a woman and her sister; that is ]abhorren $\left[\mathrm{t},{ }^{\prime 25}\right.$ we see that the author adjusted the biblical ואת אחותה to אל אחתה, which must be understood as meaning her literal sister, not as one woman to another, as Gruber suggests. ${ }^{26}$

law, his brother's widow, even after his brother's death. However, since Scripture restricts the prohibition of Lev 18:18 to בחייה "her life time," the decree cannot relate to a real sister, and must therefore be interpreted as referring metaphorically to "a wife together with another." It seems to me that this speculative consideration is not compelling, especially since CD IV:20-V:1 proffers other justifications for its prohibition of polygamy. I conjecture that Ginzberg was somewhat influenced by the Karaites, who deduce from Lev 18:18 the prohibition of polygamy; he records, however, that the polygamy prohibition is not absolute, and applies only when the second marriage is injurious to the first one, since Scripture conditioned it by the term לצרר "to vex her" (KJV). Aharon Shemesh, "4Q271.3: A Key to Sectarian Matrimonial Law," JJS 49/2 (1998) 244-263 at 245-6 also follows Ginzberg's theory, but in contrast to Ginzberg assumes that one cannot marry another woman as long as the previous divorced woman is alive. For an extensive deliberation about Shemesh's theory and motivation see section 6.4, pp. $244 \mathrm{ff}$.

21 Gruber, "Women in the Religious System of Qumran," 178-79.

22 See a more extended citation of Gruber's arguments in section 6.3.2.3.

23 See Gen 13:8, 11, 26:31, 37:19, 42:21; Exod 2:11, 32:29; Lev 25:46; Deut 1:16, 17:15; Isa 9:18, 19:2; and Jer 23:35.

24 Gruber, "Women in the Religious System," 187-8, turns the issue on its head, writing that "one of the meanings of אחות in Hebrew is 'sister' in the sense 'female sibling."

25 See Gershon Brin, "Reading in 4Q524 Frs. 15-22 DJD XXV," RevQ 74 (1999): 265-71 at 267.

26 Although this is the interpretation of the Ts, we have no reason to assume that the $\mathrm{CD}$ conflicts with the Ts. 
Relying on his conception, however, Gruber states that Lev 18:18 is the source of the prohibition on polygamy in CD IV:20-V:1. He cites Ginzberg's interpretation of Lev 18:18 as referring to the marriage of a fellow woman, ignoring the fact that Ginzberg only contends that this was the interpretation of the "Unknown Sect," not the correct interpretation of the biblical text. ${ }^{27}$

\subsubsection{2 זנות Debating Gruber's Narrow Interpretation}

Considering the prohibition of polygamy as an explicit and irrefutable Torah precept, therefore, Gruber interprets CD IV:20-V:1 as follows: "They are caught in the trap of two [sins]: in [the trap of] adultery by marrying two women in their lifetime" - comparing the transgression of polygamy to adultery, and thus translating זנות as expressing the most severe kind of sexual mischief.. ${ }^{28}$ But זנות does not denote sexual misbehaviour in most cases, either in Scripture or in Qumran literature, nor does it always suggest fornication or whoredom; ${ }^{29}$ its general connotation is of evil and unethical deeds, whether or not associated with sexual mischief. ${ }^{30}$ For example, we read in Exod 34:15: T⿱宀 "they will go astray" after their gods, and in Lev 20:5: "to go astray" after Moloch. In Isa 1:21 we read: "See how the faithful city has become a זונה prostitute"; then follows the explanation of how it has done so, and there is no connection whatsoever to sexual misbehaviour. We find the same usage in Qumran literature. In 4 Q397 (4QMMT ${ }^{d}$ ) II:12, the phrase ועל הזנות relates to the marriage of priests with Israelite women. This is a transgression connected to a sexual issue, but it is not an instance of fornication, adultery or whoredom; rather, it is compared to

27 Ginzberg, An UnknownJewish Sect, at 19 indeed notes that "this sect rejected the traditional interpretation of this verse."

28 Gruber, "Women in the Religious System," 180 n. 21, cites other scholarly interpretations of the term זנות, such as "fornication" and "whoredom," but defends his translation of "adultery." Wassen, Women, 118, translates the term as "fornication," and so does Lawrence H. Schiffman, "Laws Pertaining to Women in the Temple Scroll," in The Dead Sea Scrolls: Forty Years of Research (ed. Devorah Dimant and Uriel Rappaport; Leiden: Brill, 1992) 209-28 at 217. In fact, even a זונה "harlot" is not an extremely abominable personality, like an adulteress; only a priest is forbidden to marry a harlot, there being no such prohibition for an Israelite, and we do not encounter any sanction of defilement of her children with respect to marriage with Israelites. This is not comparable to a child born of an adulterous liaison. Marriage with a harlot may be perceived as immoral, but not prohibited.

29 In some occurrences in Scripture the term זנות denotes whoredom.

30 Even in our modern language, the term זנות in Hebrew or "prostitute" in English metaphorically describes a person who willingly uses his or her talent or ability in a base and unworthy way, usually for money. 
the prohibition against kil'ayim, the mixing of two different species of animals or plants, and defiles the holy priestly seed, as appears in the parallel 4Q396 (4QMMTc) IV:10. In 1QS I:6, the phrase ועיני זעות explains its reference to לעשות כול רע "to do every evil thing” (1QS I:7)—again, a generic expression of wicked deeds. ${ }^{31}$

The use of זנות CD VI:21-VII:2 seems to me the overwhelming and definitive evidence of its generic meaning of wickedness, including sexual misdeeds among others. We read there: "and to seek each the welfare of his fellow, never betraying a family member; keeping away from הזונות wickedness according to the ordinance; ${ }^{32}$ reproving each his fellow according to the command, but not bearing a grudge." There is not the slightest hint of sexual misdeeds in these verses, nor in the antecedent or subsequent verses. In CD VIII:5, זונות ז זנות> appears in a description of a long list of misdeeds, among them just one obscure phrase, ויגשו לזמה, that may or may not refer to a sexual misdemeanour, depending on the interpretation. Cook translates: "each hating his fellow; each of them kept away from nearest kin but grew close to זמה indecency; they vaunted themselves in riches and in ill-gotten gains" (CD VIII:6-7). The interpretation of ויגשו לזמה as "but grew close to indecency" is vague and does not clearly express the author's intent. Further, all the 1 "vav" con-

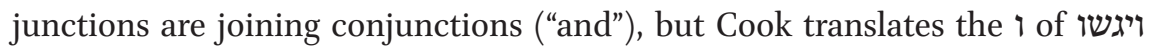
as "but," an opposite conjunction, because in his translation this phrase does not connect to the antecedent and subsequent phrases, as all others do within the extended lemma. In contrast, García Martínez and Tigchelaar translate, "And each one hating his fellow. Each one became obscured by blood relatives and approached for debauchery." ${ }^{33}$ The interpretation of this entire sentence has no relationship to the text, and it also avoids translating the joining conjunction "and" at the beginning of the problematic sentence, since there is indeed no literary or factual connection to the antecedent phrase, as argued above. Both translators seem to have ignored the simple meaning of the phrase "ומבשרך לא תתעלם: and not whose source is Isa 58 ויתעלמו איש בשאר בשרו

31 John Kampen, "The Matthean Divorce Texts Reexamined," in New Qumran Texts and Studies, Proceedings of the First Meeting of the International Organization for Qumran Studies, Paris 1992 (ed. George J. Brooke with Florentino García Martínez; Leiden: Brill, 1994), 149-67, who emphasizes the sexual character of זנונת as fornication and whoredom in Qumran literature, admits at 165 that "at times the term also has broader connotations." I maintain that the broader use of the term occurs often, and therefore cannot serve as indication that a wicked deed with the sobriquet זנות necessarily indicates fornication.

32 Cook, DSSEL, translates הזונות as fornication, disregarding the context.

33 In The Dead Sea Scrolls Study Edition (ed. García Martínez and Tigchelaar). 
to turn away from your own flesh and blood." 34 Without question, this source passage indicates the meaning and spirit of the phrase, which compels us to connect the antecedent and succeeding phrases, ignored by both translators. In consequence, I think that we must interpret זמה here as a generic expression of wickedness, similar to זנות. Although the term זמה is used in Lev 18 and in other occurrences as associated with sexual misdeeds, it appears often in association with wicked deeds and evil intentions. ${ }^{35} \mathrm{In}$ the context of our text it signifies bad intentions to cheat one's relatives. Furthermore, the term נגש, used by the author in connection with זמה, does not appear in Scripture in association with a sexual topic. ${ }^{36}$

\subsubsection{Further Arguments against Gruber's Theory}

Thus, Gruber's conjecture that Qumran scholars interpreted Lev 18:18 as prohibiting polygamy, and hence that marrying a second woman was considered similar to adultery, has no support. The use of בחייהם in the CD and כול ימי חייה in ${ }_{11}{ }_{19}\left({ }_{11 Q T e m p l e}{ }^{a}\right.$ ) LVII:18 is no evidence that their authors determined the prohibition of polygamy from the biblical use of the similar term בחייה in Lev 18:18, as Gruber claims. ${ }^{37}$ If this were the case, the author of the polemic CD rule would have justified it with the phrase "as is written/said," with or without quoting the biblical verse, as is common in the polemic ммт. Instead, however,

34 Tתe term תתעלם also appears in Ps 55:2 (55:1 in the KJV) in the phrase ואל תתעלם מתחנתי "do not ignore my plea." Although the context here requires a differing translation, the essence of תתעלם is conveyed similarly in both passages. Aharon Shemesh, "Scriptural Interpretations in the Damascus Document and their Parallels in Rabbinic Midrash," in Damascus Document, 161-75 at 164, correctly interprets the first part of CD VIII:6-7: "and each ignored the relation of his flesh," but then translates: "and they drew near (one to another) for incest," which is a literal translation of the text, but one that does not fit into the context; that is, to the antecedent and subsequent phrases that refer exclusively to social misdoings, not to sexual issues. Shemesh does not delete the joining conjunctions, but the interpretation, which suggests incest, is out of place with the preceding accusation of hating one's brother and ignoring the relationship, and the subsequent accusation of striving for wealth and profit, which seems to follow organically.

See, for example, Isa 32:7; Jer 4:28, 23:20, 30:24, 51:11; Ezek 16:58, 22:9; Ps 26:10; Prov 21:27 and many others in which the term זמות in its various grammatical forms are used metaphorically to express wickedness or evil intentions. The term זמם for the false witness in Deut 19:19 comes from the identical root.

36 See my interpretation of the term נגש in Exod 19:15 in Chapter 4, p. 134.

37 Gruber, "Women in the Religious System," 178, 187. The entire text of the lemma in 11 Q19 is so different from that of Lev 18:18 that the similarity of the one phrase in both texts - citing an integral element of the rules — cannot definitively indicate that Lev 18:18 is the lemma's source. 
he justifies his prohibition by a logical deduction from two biblical narratives; ${ }^{38}$ since he avoids citing Lev 18:18 in support of his halakhah, we may assume that the $\mathrm{CD}$ author, like the rabbis, ${ }^{39}$ interpreted this verse as a prohibition on marrying two real sisters. Gruber perceives the author's justification for his prohibition of polygamy - "the principle of creation is "male and female He created them' (Gen 1:27), and those who went into the ark 'went into the ark two by two'" (CD IV:21-V:1) — as additional support to the prohibition of Lev 18:18 for the substantiation of the CD author's decree. ${ }^{40}$ To justify the odd procedure of citing logical deductions instead of the explicit biblical verse, he builds a complex theory, arguing that since the "author of $\mathrm{CD}$ was fully aware that members of Jewish sects who believed that God's moral economy countenances polygamy would not be convinced by what they would regard as a thoroughly tendentious exegesis of Lev 18:18 ... [he] brilliantly invoked the normative biblical narratives of Creation and the Flood." ${ }^{41}$ An apparently careless statement immediately catches the eye, namely that the Pharisees are perceived by the $\mathrm{CD}$ author as "members of Jewish sects"; it seems to me that the common view is the opposite (that is, that the Qumran group separated from the bulk of the Israelite society), based on many sources but particularly the explicit statement in 4Q397 (4QMMTd) IV:7. This is not the only oddity among Gruber's assertions on this topic, as we shall see below.

I find it somewhat strange that Gruber first tries to convince readers that the obvious meaning of ואשה אל אחתה in Lev 18:18 is "a woman to her fellow woman," because this interpretation "is attested eight more times in Scripture," and that this verse "is the only law in Scripture that pertains to the question of whether God's law allows or disallows polygamy,"42 then suddenly turns around and alleges that the $\mathrm{CD}$ author did not cite Lev 18:18 to justify the prohibition on polygamy because Qumran's opponents would perceive this as an unconvincing and tendentious exegesis. The argument that an implicit deduction from a narrative would be more convincing than quoting a scriptural decree does not make sense; a simple interpretation of a clear biblical verse, as Gruber earlier claims, is always stronger and more convincing than a deduction from a biblical narrative. Further, it does not conform to Qumran's polemic writings

38 Crawford, "Not According to Rule," $127-50$ at 133, writes: "The prohibition of polygamy is made by reference to the stories of creation and the flood, as portrayals of God's real intentions for humanity."

39 See, for example b. Yeb. $3 \mathrm{~b}$ and b. Yeb. 28b.

40 Gruber, "Women in the Religious System," 183.

41 Ibid., 186 (Original text reads “... they brilliantly invoked...”).

42 Ibid., 178. 
attempting to convince their opponents in MMT and in $\mathrm{CD}$, in which the biblical verse is cited or alluded to, and then following up with their interpretation. In 4Q394 3-10 (4QMMTa) II (3-7ii):14-16, for example, the debate starts with: "[And concern]ing כתוב what is written" (we do not know whether the biblical verse was quoted or only alluded to, as is common in the MMT); the authors' interpretation follows, with no logical or other support: "And we חושבים think that the Temple..." In 4Q394 3-10 (4QMMT') III (8iii):7-9, we see the same principle in operation, but in reverse order-first the interpretation, then the quotation of the biblical verse: "[And concerning the eating, חושבים we think that one can eat] the fetus - missing text- [ so and] the word כתוב is written."

In the $\mathrm{CD}$, we find identical circumstances in which biblical verses are cited along with Qumran's interpretation, mainly in relation to prophecies, but also in relation to halakhot in CD IX:2-8, X:14-17, XI:17-18, and XVI:6-9. I would particularly emphasize the style of Qumran's polemic argumentation in CD $\mathrm{V}: 7-11$ with their opponents, who did not accept their rule prohibiting marriage between uncle and niece-similar in certain ways to our subject, the prohibition of polygamy. Moreover, with respect to polygamy, Lev 18:18, interpreted as Gruber suggests, would clearly and explicitly prohibit polygamy; by contrast, Lev 18:13, the verse cited in CD V:8, does not explicitly prohibit marriage with a niece, so that a logical deduction by the author is necessary to arrive at the desired conclusion. Nevertheless, the author of V:8 cites the biblical verse without fear that his opponents will not accept it; we have seen the same in 4Q394 3-10 (4QMMTa) III (8iii):7-9, quoted above, and we observe it in $4 \mathrm{Q}_{395}\left(4 \mathrm{QMMT}^{\mathrm{b}}\right): 5^{-6}$. Yet the author of CD IV:20-V:1, according to Gruber, does not cite the explicit biblical support for his position with respect to polygamy because his opponents would not be convinced by it. Gruber's explanation for the missing citation therefore holds no water. I also wonder why Gruber claims that "the lawyers who composed the Qumran law books," like the sages of the mishna, sometimes go their "own way with respect to a specific subject or legal detail" because neither was "bound by the Lutheran doctrine of sola scriptura." ${ }^{33}$ As I have argued elsewhere, ${ }^{44}$ and as I think is commonly acknowledged in one way or another, the Qumran scholars usually adhered to the simple and straightforward interpretation of the biblical commands, in contrast to the rabbis' midrashic interpretive system. ${ }^{45}$ In particular, in the case of the CD's prohibition of polygamy, the subject of Gruber's thesis,

43 Ibid., 188.

44 Heger, Challenges, 29-35.

45 Ibid., 21-26. 
its author would have followed the simple and explicit meaning of Lev 18:18 by interpreting it as relating to two women, if that were as Gruber argues its obvious meaning; ${ }^{46}$ there would be no divergence from the pentateuchal law, and no need for a higher authority to justify it, as Gruber argues.

Further, Gruber follows Neusner in arguing that it was the rabbis who misinterpreted the "obvious meaning of Lev 18:18" in order to permit polygamy. ${ }^{47}$ He then states that "it has been clear that the persons whose practices are here [i.e., in CD IV:20-V:6] condemned are the spiritual progenitors of the sages of the mishnah and tosefta, who are commonly identified with the Pharisees of Josephus and the New Testament"48_implying that the Pharisees had already misinterpreted Lev 18:18 to permit polygamy. There is no doubt that in many cases the rabbinic writings follow the Pharisaic tradition, but it is also evident that the rabbis wrote many innovative halakhot. But however one perceives this connection, Gruber has no evidence that polygamy was prohibited initially and that the Pharisees permitted it by incorrectly interpreting Lev 18:18, as he asserts, or for that matter that it was permitted and practised in Israel but the Qumran scholars prohibited it.

To fit his theory that polygamy was initially prohibited, Gruber states, again without explanation or evidence, that the assertion in $C D$ V:1-5 that a "sealed book" containing the prohibition on polygamy both for all Jews and for the king "was discovered in the Temple in the eighteenth year of the reign of King Josiah."49 Thus, it relieves David, the Patriarchs, Elkana et al. of having transgressed the law, and confirms that polygamy was prohibited since then. He overlooks, however, the CD's explicit assertion that the "sealed book" was opened only by Zadok, Qumran's leader. ${ }^{50}$ We must assume, therefore, that the book was opened by the Teacher of Righteousness, and consequently that polygamy was permitted until that time. ${ }^{51}$ Sound logical consideration of the relevant texts from different sources would suggest that polygamy was the dominant

\footnotetext{
46 Gruber, “Women in the Religious System," 178.

47 Ibid.

48 Ibid., 179 n. 20.

49 Ibid., $184-5$.

$50 \quad$ CD V:4-5.

51 The Teacher of Righteousness is mentioned in CD and other writings as the spiritual leader who revealed hidden things to the ignorant people (as in CD I:7-12, XIX:35-XX:2, XX:28 and 32; 1QpHabVII:4; and 4Q173 (4QPs $\left.{ }^{\mathrm{b}}\right)$ I:3-4); but their opponents did not believe him (as in 1QpHab II:2) or did not help him against the Man of the Lie (1QpHab V:9-11). The similarity between some of these verses and our verse is striking. The name Zadok does not appear in 2 Kgs $22-23$, which narrates the events to which Gruber asserts that
} 
custom in Israel until late in the period of the Qumran community and that at that time, as noted above, the Qumran scholars (alluding to a revelation by the Teacher of Righteousness), ${ }^{52}$ and plausibly some other minor segments of Israelite society, attempted to eradicate this custom.

I also dispute Gruber's allegation that since Qumran revered Jubilees, which relies on the higher authority of "the Heavenly Tablets" in its halakhot, Qumran halakhot are based on the same authority. ${ }^{53}$ As noted above, the Qumran scholars habitually adhered to the simple interpretation of biblical rules, without appeals to any higher authority. In fact, as I have argued elsewhere, ${ }^{54}$ they do not justify the correctness of their interpretations by reference to the Heavenly Tablets, even in their polemical writings or when accusing their opponents of distorting the interpretation of biblical commands. The reference in the text to a passage from Jubilees in CD XVI:4 does not represent evidence of the significance and authority of its halakhot, since the passage in question relates to the "divisions of time," not to halakhot. Further, Jubilees does not prohibit polygamy, and the CD author does not mention the "Heavenly Tablets." In light of everything noted above, I postulate that the prohibition of polygamy in the CD was deduced, as clearly and explicitly stated, by means of logical considerations and deductions from the biblical narratives; there is no valid reason to search for other justifications than those indicated by the author.

As I understand the CD lemma, the author distinguishes between the general prohibition on polygamy for all Israelites, on the one hand, and the particular rule for the king. The latter rule, I conjecture, was brought up to justify David's behaviour in marrying many wives, in violation of the biblical rule in Deut 17:17: "He must not ירבה take many wives, or his heart will be led astray. He must not accumulate large amounts of silver and gold." A separate command prohibiting the king from marrying more than one woman, as interpreted by the $\mathrm{CD}$ author in IV:20-21, was necessary because otherwise one might think that one of the king's privileges is permission to have more

CD V:2-5 refers; the High Priest mentioned is Hilkiah, and there is no discussion of his family of descent.

Although I have written in Paul Heger, "The Development of the Qumran LawNistarot, Niglot and the Issue of 'Contemporization,' RevQ 9o/23, 2 (2007): 167-206 at $182-3$, that the Teacher of Righteousness mainly revealed mysteries, the future, the time of the eschaton, and similar doctrinal issues, rather than the correct interpretation of the halakhot, it fits our thesis here, since the $\mathrm{CD}$ does not assert that he established the prohibition of polygamy but, rather, declares that he revealed the hidden book in which it was written from time eternal.

53 Ibid., 188.

54 Heger, Challenges, 219. 
than one wife. ${ }^{55}$ In fact, on the basis of the rule in Deut 17:17, quoted verbatim in $\mathrm{CD}$ V:1-3, one would understand that a king may marry more than one wife, but not too many, as is the common meaning of ירבה. The preceding v. 16, using the identical term, obviously does not mean that he may have only one רבה horse; the same applies to the other grammatical formulations of the root in Scripture, as for example in Gen 16:10, Exod 32:13 and Lev 26:9—it always means "multiplying" or "more than one." ${ }^{\text {" }}$ Reverting to the question posed in the title, we may assert that the rule in the Ts is complementary to that of the CD. Although the latter mentions the prohibition on the king's/prince's marrying more than one woman, it does not indicate the particular halakhic details of the prohibition, which appear in the Ts. Since the CD's main motive in referencing this passage is not to promulgate the rule, but to defend the conduct of David, the author is not expected to give these details.

\subsubsection{The Source of the Prohibition on Polygamy in 11Q19 LVII:15-19}

As we have seen, the Ts prohibits the king from marrying another woman as long as his first wife lives. It is unclear from the text whether the same rule applies also to all Israelites and whether it accords with the CD rules, a question we shall try to answer in the study. Further, whereas the CD justifies its prohibition of polygamy by means of a logical consideration, the Ts does not indicate a rationale for this particular unique rule, which does not appear in Scripture. Deut 17, as we have seen, cannot be interpreted as referring to no more than one wife, and ${ }_{11}{ }_{19}$ (11QTemple ${ }^{a}$ ) LVI:17-19 — which quotes it almost verbatim - prohibits only marriage with many wives. ${ }^{57}$ Some scholars have

55 Gruber, "Women in the Religious System," 187, logically explains Qumran's strategy to enact special legislation for kings, because in the Ancient Near East, marriage or concubinage with many women "was generally confined to royalty and other wealthy and powerful men."

$5^{6}$ The Rabbis indeed disputed how many women the king may have (m. Sanh. 2:4): that is, what constitutes too many. They argued further about the determining factor of the prohibition: is it the number of wives or the danger of being led astray by them, as seems to be the rationale for the prohibition?

57 Johann Maier, The Temple Scroll: An Introduction, Translation \& Commentary (trans. Richard T.White; ed. David J.A. Clines and Philip R. Davies; Sheffield:University of Sheffield, 1985), 124, writes: "the Scroll clarifies the biblical text; the many women are the subject of the subordinate clause; they turn the king's heart away from God." In contrast, Schiffman, "Laws Pertaining to Women," 212, argues that this verse also forbids polygamy, and hence "polygamy by the monarch is proscribed twice." I dispute Schiffman's interpretation of 11Q19 LVI:18-19; it does not concord with the text, which explicitly indicates many wives, as 
again assumed that since the text of the Ts mentions כול ימי חייה, the author deduced the prohibition of polygamy from Lev 18:18, in which בחייה appears. ${ }^{58}$

I do not see eye to eye with these scholars on this assumption; the two rules in Deut 17 and Lev 18 are so different, in both structure and essence, that the occurrence of a similar term in both rules cannot be perceived as indicating that one is the source of the other, nor as decreeing identical rules through the application of a rabbinic Gzera Shava midrashic interpretation. ${ }^{59}$ I see rather a similar structure and essential affinity between 11Q19 LVII:15-19 and the rules governing marriage restrictions for the High Priest in Lev 21:13-14. ${ }^{60}$ "The woman he marries must be a virgin. He must not marry a widow,

Schiffman translates from the original Hebrew ירבה. I perceive it rather as an introduction to the Law of the King, paraphrasing almost verbatim Deut 17:15-20, followed by a detailed record of the supplementary rules of the Ts. This method is similar to Vermes' Clarifying Additions and Recasting and Supplementations (see discussion on Qumran's interpretive methods in Heger, Challenges, 80-88). In Schiffman's conclusion to this study, at 228, he determines that the author of the Ts "echoes either the simple meaning of the biblical text, or interpretations common in his time." Since in this case it is obvious that Qumran's interpretation was not the common exegesis of the time-polygamy was the norm-the author of the Ts would have decided the halakhah according to the simple meaning of the biblical text, which prohibits many wives. I fully agree with Schiffman that the Ts, like Qumran, adhered to the simple scriptural meaning in interpretations, but since there is no explicit biblical decree prohibiting polygamy, Qumran decided the halakhah on the basis of a simple, logical consideration, as quoted in CD IV:20-V:1. On this topic, see Heger, Challenges, $38-40$.

$5^{8}$ John Kampen, "A Fresh Look at the Masculine Plural Suffix in CD IV:21," RevQ 16 (1993) 91-97 at 93, refers to the same term עליה in Lev 18:18 and 11Q19 LVII, and deduces that the

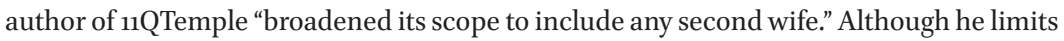
this restriction "to the lifetime of the wife, the resulting legislation is now applied to any other woman while the wife is alive." While Kampen declares: "we do have to accept the evidence [of LVI] that the scroll intends to limit the divorce regulation to the king" (96), he nevertheless assumes, without any textual support, that some persons would consider that a "standard of greater purity" mandated for "some office holder within Israel really should be applied to everyone. In addition to my primary argument against the use of a Gzera Shava by Qumran, it seems to me that a king cannot be perceived as "some office holder," to stimulate emulation in all Israel; I also question Kampen's assertion that the restriction to marry a divorcée is a matter of purity.

59 As I have written at length in Challenges, 29-35, and as is generally thought, Qumran scholars deprecated such rabbinic interpretive methods.

6o Steven D. Fraade, Legal Fictions; Studies of Law and Narrative in the Discursive Worlds of Ancient Jewish Sectarians and Sages (Leiden: Brill, 2011) 296-7 writes: "in this regard [the decree to marry a virgin from his own people] the king [according to ${ }_{11} \mathrm{1}_{19} \mathrm{LVII}$ ] is to behave in a high priest-like manner." 
a divorced woman, or a woman defiled by prostitution, but only a מתולה virgin from מעמיו his own people." In 11 Q19 LVII we read: "And he shall not take a wife from all the daughters of the nations, but from his ממשפחת אביהו father's family he shall take unto himself a wife, from the מבית אביהו ממשפחתו family of his father. And he shall not take upon her another wife, for she alone shall be with him all the days of her life. ${ }^{61}$ But should she die, he may take unto himself another (wife) from מבית אביהו ממשפחתו the house of his father, from his family."

The triple repetition of this concept-and ממשפחת אביהו,מבית אביהו משפו משית מ-within the short Ts lemma on the status of the women the king may marry leads the imagination to the similar particular restrictions on the women the High Priest may marry. We must consider that there is no hint in Scripture that the king must marry even a Jewish woman, yet the TS insists that she must be not only Jewish but from an Israelite royal family, just as a priest may marry only a priestly daughter according to $4 \mathrm{Q} 397\left(4 \mathrm{QMMT}^{\mathrm{d}}\right)$ II:12. I hypothesize, therefore, somewhat similarly to Schiffman's and Fraade's assertions, ${ }^{62}$ that the Ts author compared the king to the High Priest with respect to marriage rules, and decreed some particular genealogical and other requirements for a king's wife. We observe in $1_{2} 8^{\mathrm{a}}\left(1 \mathrm{QS}^{\mathrm{a}}\right)$ II:11-14 an eschatological association between the Messiah and the Priest, plausibly influenced by the Qumran concept that a High Priest could marry only one woman, deduced from the use of the singular form בתולה in the relevant biblical rule in Lev 21:13, and reiterated in v. 14. If, as I have suggested, the king is compared to the High Priest, the same rule applies to him. The king must live with one wife as long as she lives, and cannot divorce his wife, like the High Priest to whom, as I propose, he is compared in 11Q19, and who cannot marry a divorcée or a widow. We have no idea why a priest cannot marry a divorced woman, or a High Priest a widow; Scripture tells us that marrying a widow or a divorced woman impairs holiness (Lev 21:7 and 21:15) but does not explain why.

Since special restrictions on marriage are imposed on the High Priest, it is reasonable to hypothesize that the author of the Ts rule, comparing the king to the High Priest with respect to marriage, imposed some particular restrictions on him with respect to divorcing his wife. I am aware that this chain of reasoning does not constitute hard evidence for my assumption, but since we have no

61 Ibid., at 297, Fraade assumes that the Ts rule that the king must not "marry another woman so long as his previous wife is still alive [is] based on an interpretation of Lev 18:18." His presumption is based on the occurrence the term חייה in 11Q19 LVII, similar to the term בחייה in Lev 18:18, a speculation, which I disputed earlier in the chapter.

Schiffman, "Laws Pertaining to Women," 216. Re Fraade, see n. 60. 
idea what motivated either the biblical restrictions on priestly marriage or the marital restrictions on the king set out in the Ts, my proposal seems to me to offer a plausible explanation.

\subsubsection{Further Questions on the Polygamy Prohibition}

A more difficult question arises regarding the levirate obligation: namely, what is the rule if the brother is married, and thus would be practising polygamy (prohibited by Qumran law) if he married his brother's widow? The rabbis promulgated a rule that absolves the obligation of levirate if marrying the widow would conflict with the Law, as for example if it would create an incest relationship ( $m$. Yeb. 1:1). In that case she need not even perform the ceremony of "taking off the sandal" (Deut 25:9). However, neither Scripture nor Qumran addresses such a contingency. ${ }^{63}$

I would hypothesize that the Qumran scholars were aware of this problem and devised a solution, but we do not know whether they suspended the obligation of levirate altogether in such cases, as the rabbis did in cases of incest, or whether they decreed the performance of the ceremony of the sandal. ${ }^{64}$ The second contingency, however, would be unreasonable and unjust; it would dishonour a family for no evil deed. ${ }^{65}$ I would hypothesize a third contingency; since the Qumranic prohibition of polygamy is justified by its departure from the divine creation principle that one male and one female ensure the survival of humanity, one could envisage that this principle is not violated by a levirate relationship. In effect, the levir begets a son for his deceased brother, who

63 Gershon Brin, "Divorce at Qumran," in Legal Texts and Legal Issues: Proceedings of the Second Meeting of the International Organization for Qumran Studies, Published in Honour of Joseph M. Baumgarten, Cambridge, 1995 (ed. Moshe Bernstein, Florentino García Martínez and John Kampen; Leiden: Brill, 1997) 231-44 at 239 alleges that the author of the Ts "does not copy the law of the levirate marriage because this conflicted with his own view concerning the prohibition of marriage with a brother's wife." I am not convinced that because of an ex silentio consideration one could impose on the Ts author and the Qumran group the annulment of an explicit biblical law. I rather prefer to admit my inability to resolve every difficult problem.

64 In fact, ${ }_{11}{ }_{19}$ (11QTemple ${ }^{a}$ LXVI:8-11 qualifies the biblical obligation of the seducer to marry the girl only if if the marriage is not against the law, but we do not encounter such provision in Qumran writings.

65 Contemporary circumstances, namely that the levirs married their brother's widow for selfish motives, rather than to fulfill the Torah precept, convinced the rabbis (m. Bek. 1:7) to prefer the ceremony of the sandal, Scripture's second-rate alternative, to the accomplishment of the levirate decree. Thus, practical consideration motivated them to overturn the biblical choice. 
has the God-given right to his genealogical survival, the justification for the levirate regulation (Deut 25:6). Such a contingency would be a legal fiction, but so is the levirate decree, and as it seems, it was part and parcel of the conventional social order that acknowledged the reality of legal fictions, deeming them as concrete facts. The son of the levir was actually perceived to be the son of his brother, not his own. Onan did not display any reluctance to have Tamar as his wife and enjoy sexual intercourse with her; he objected only to the reality that the offspring would not be legally his, as is clearly evident from Gen 38:9. The deemed identity of his offspring as his brother's son overwhelmed in Onan's perception the physical reality of the child being his own son. Similarly, Sarai, Rachel, and Leah gave servant girls to their husbands when they could not bear children, of their own initiative, not that of their husbands, as אבנה Scripture emphasizes. The literal implication of the explanatory phrase ממנה "I may be built from her"66 is vague, but a Babylonian contract quoted by Westbrook indicates that in the Ancient Near East, children born in such circumstance are deemed to be the children of the wife, the mistress of the house, not of the servant who bore them. ${ }^{67}$ Hence, such a contingency, could as postulated be perceived as reasonable, and would answer the difficult question posited above regarding Qumran's practice of the levirate decree when the brothers of the deceased were already married.

Lastly on this topic, Deut 21:15 (relating to two children from two wives), which some scholars have used to demonstrate that Scripture permits polygamy, creates no such problem, since it does not say that the man had the two wives at the same time: he could have loved one and hated the other even if he married the second only after the death or divorce of the first.

\subsubsection{Thoughts on the Motive behind Qumran's Prohibition of Polygamy}

We may now return briefly to the question of what could be envisaged as the philosophy or motive behind Qumran's prohibition of polygamy at a time when the majority of Israelites, including leading Israelite figures, seem to practise it. As I have mentioned above, I would suppose that the Qumran scholars were convinced that according to the Torah narratives, polygamy is prohibited because it is against the divine intent; no practical or other considerations influenced their halakhic decisions in general, or the prohibition of polygamy in particular.

66 Gen 16:2 and 30:3. Scripture does not inform us of Leah's purpose giving her servant Zilpah to Jacob (Gen 30:9), but since it is recorded close to Rachel's deed and explanation, it is pretty obvious that she acted for the same reason.

67 Raymond Westbrook, Old Babylonian Marriage Law (Horn, Austria: F. Berger, 1988) 107. 
I believe that at the time of Paul and his writings (e.g., 1 Tim 3:2-5, 3:12; Titus 1:6), there were Jews outside Qumran who opposed polygamy; we do not know, however, whether they were indeed convinced that the creation and Noah narratives came to teach us the prohibition of polygamy, or whether they opposed it for practical reasons, including the consideration of the first wife's discontent ${ }^{68}$ or because of chastity considerations, as seems to have been Paul's motive. ${ }^{69}$ At any rate, I do not think that those Jewish groups (including Qumran) that prohibited polygamy were driven or influenced by the "principle of equality between the sexes created by the legislation of monogamy," as Gruber alleges. ${ }^{70} \mathrm{He}$ further asserts that the same principle of equality of the sexes underlies the Qumran rule of CD V:9-10, which prohibits marriage between uncle and niece, parallel to the biblical prohibition against a man's marrying his aunt. Gruber perceives this rule as Qumran's declaration of equality between men and women, ignoring the fact that it appears amongst incest prohibitions that have no association with equality. Similarly, the prohibition of polygamy does not indicate equality between the sexes with respect to social and legal issues. Each topic is sui generis, and one has no automatic implications for the other. In fact, Qumran texts demonstrate the differences between men and women, as amply displayed in this book. 4Q416 (4QInstr ${ }^{\mathrm{b}}$ ) 2iv:6-11, declaring that Scripture granted the husband the authority over his wife, "so that she should walk in/according to thy good pleasure," and similar expressions, seems to me the conclusive antithesis of Gruber's allegation in this respect.

\subsubsection{Interim Conclusion on the Source of the Polygamy Prohibition in the $C D$}

I believe I have demonstrated the flaws of Gruber's theory that Qumran understood Lev 18:18 as relating to two women, not to two sisters, and that this

68 We encounter such consideration in a dispute between two Amoraim (Fourth Century $\mathrm{CE})$ as to whether a man can marry another woman in addition to his first wife, against the latter's will. (b. Yeb. 65a). One declares that in such circumstances the husband must (according to the interpretation of the commentator Ritb"a) divorce the first wife and pay her the ketubah, but another one declares that a man can marry as many women as he wishes, subject to have the financial means to maintain them properly.

69 Instone-Brewer, "Jewish Women Divorcing their Husbands," 355, writes that "Monogamy is another teaching that became popular very early in Egypt and spread to sectarian Judaism, but it spread only gradually through rabbinic Judaism." Instone-Brewer, Divorce and Remarriage, 22, writes that the LXX, Qumran and Targumim were among the "many voices teaching that polygamy was against God's ideal."

70 Gruber, "Women in the Religious System," 189. 
verse was the basis of their prohibition of polygamy. The strongest argument against this thesis, I think, is the fact that the $\mathrm{CD}$ author makes no such claim, but indicates other motives to justify the prohibition; I have also shown the flaw in Gruber's assertion that "the lawyers who composed the Qumran law books, ${ }^{\prime 71}$ like the Sages of the Mishna, went their own way in the interpretation of Scripture, rather than following a simple reading of the text. It seems strange to me that he makes this statement in connection with the prohibition of polygamy, when according to his own argument the CD author interpreted Lev 18:18 in the most straightforward way.

\subsection{Does CD Prohibit Divorce?}

The simple meaning of the CD text IV:20-V:2 prohibits polygamy and does not relate to any other issue, such as divorce or remarriage after divorce, as some scholars have claimed. I suggest perceiving בחייהם-understood as relating to the lives of the women (emended to בחייהן or perceived to be grammatically correct as relating to women in the plural) — to be interpreted: "as long as they [man and woman] live together," that is, as long as they are not separated (by divorce or by death); the masculine plural בחייהם is thus justified, since it relates to a man and woman living together. ${ }^{72}$ The masculine plural may in fact be assumed to be a deliberate choice by the author to indicate his intent: namely, that it is prohibited to have two wives at the same time, as long as the first wife still lives together with the man. ${ }^{73}$ This prohibition on living with two women at the same time, and this prohibition alone, is logically supported by the CD author through his allusion to the Creation and Noah narratives. For the survival of humanity, God created one man and one woman, and for the preservation of the other species he commanded Noah to save in the Ark one male and one female of each.

When we come across a difficult ancient text and are tempted to interpret it in association with other texts, we should first ask ourselves whether we

71 Ibid., 188.

72 Ginzberg, An Unknown, 20 understands it likewise, writing: "The addition of בחייהם in our text is borrowed from Scripture and means only that this prohibition of marriage differs from all the others in so far as it is in force only so long as a man lives with his first wife in marital union."

73 Schiffman, "Laws Pertaining to Women," 217 proposes a somewhat similar understanding of the term בחייהם, as referring to "both parties to the divorce," leading to a different conclusion than my proposition. 
would come to the same conclusion in the absence of our knowledge of these other texts, as I believe is the case with the assertion that the $\mathrm{CD}$ text prohibits remarriage after divorce, based on its use of בחייהם. A further inducement in this direction was probably constituted by the texts of ${ }_{11}{ }_{19}$ (11QTemple ${ }^{a}$ ) LVII $^{74}$ and the New Testament, which deduce a prohibition on divorce from Gen 2:24. I doubt very much whether the same conclusion would have been reached without considering these texts; the problem of the term בחייהם would have been resolved in different ways, as indeed Vermes and other scholars have done. ${ }^{75}$ In fact, it is not the text of 11 Q19 LVII that led scholars to interpret CD IV as relating to divorce and subsequent remarriage; rather, it seems to me, the greatest influence (conscious or not) is the prohibition of divorce and remarriage in the New Testament writings, which deduce it from the same biblical text quoted in part in our lemma. The common prohibition of polygamy in the $\mathrm{CD}$ and in the NT plausibly rationalized the scholarly assumption that divorce was prohibited in Qumran.

However, the comparison of CD IV:20-V:2 with Mark 10:6, and the consequent influence on scholarly considerations, is not justified, since the two sources build their theories on different biblical citations and interpretations. As Doering convincingly demonstrates, Mark's rule prohibiting divorce is based mainly on Gen 2:24, "becoming one flesh," although Gen 1:27 is also mentioned. ${ }^{76}$ I would emphasize the stronger utterance in Mark's conclusion-"So then, what God has joined together, let man not separate"-as the core of his justification for the divine prohibition of divorce. This is Mark's interpretation of Gen 2:24. This verse is not mentioned at all in Qumran writings about polygamy (neither the CD nor the TS), which indicates that the Qumran authors did

74 Instone-Brewer, Divorce and Remarriage, 63 writes: "The publication of the Temple Scroll appeared to support this emendation [of the term בחייהם] into feminine" thus, interpreting it as prohibiting divorce and remarriage as long as the woman lived.

75 Vermes, "Sectarian Matrimonial," 56, writes that the passage "leaves the question of remarriage by divorcées and widowers intact." Holmén, "Divorce in CD 4:20-5:2 and 11Q19 57:17-18," 397-408 at 402, writes that "on the basis of the linguistically most obvious reading of בחייהם... the passage would simply be irrelevant to the issue of divorce."

76 Lutz Doering, "Marriage and Creation in Mark 10 and CD 4-5," in Echoes from the Caves: Qumran and the New Testament (ed. Florentíno García Martínez; Leiden: Brill, 2009), 13363 at $136-37$, claims that although the core of Mark's argument in vv. 6-8 "is a combination of two passages from the creation account," and "the argument is synthetical, with each of the proof-texts offering one 'hook,' on both of which it rests. It culminates, however, in the final statement of Gen 2:24 on becoming 'one flesh.' This is underscored by the conclusion, introduced by $\tilde{\omega} \sigma \tau \varepsilon$, in v. 8b, 'Thus, they are no longer two, but one flesh'” (author's italics). 
not interpret Gen 2:24 in the same way as Mark, and do not use it as support for banning polygamy.

The CD gives no explicit biblical support for its prohibition on polygamy, and instead justifies the rule by means of a logical consideration. Had the Qumran scholars understood the phrase "one flesh" as the author of Mark did, they would have quoted it in support of their halakhah, particularly if they had wished to prohibit remarriage after divorce. In fact, however, CD V:1-2 offers biblical support only for the specific prohibition against polygamy on the part of the king, citing the author's interpretation of לרא ירבה-a weak support in itself, since a simple interpretation denotes a prohibition of many wives, not two, as I have argued above. The CD does not quote Gen 2:24 at all, as argued earlier, and this fact demonstrates that the rule in CD IV:20-V:2 has no connection with Mark's theory that man should not separate what God has joined, as recorded in Gen 2:24. Moreover, we do not encounter in Jewish writings the concept that marriage is a sacrament, joined by God; hence, Mark's motive is not relevant in any case.

Does the CD then prohibit divorce? We have evidence from CD XIII:17 that divorce was practised in Qumran, and we have no indication that one cannot remarry after divorce; therefore, we have no logical or other reason to assume such a prohibition, particularly since Scripture explicitly permits divorce in Deut 24:1-4. ${ }^{77}$ We also observe from Jesus' debates on this issue (Matt 19:3-12; Mark 10:1-12) that permitting divorce was the usual practice in Israel, and there is no justification for the argument that the Qumran texts promulgated a rule that blatantly conflicts with Scripture. ${ }^{78}$ If such a rule existed, there would be

77 The existence of divorcées in Israel is documented in Scripture; Lev 21:7 and 21:14 prohibit priest to marry divorcées, implicitly permitting Israelites to marry them. Deut 24:1-4 explicitly permits remarriage after divorce.

78 The phrase כי שנא שלחin Mal 2:16—“The man who hates and divorces his wife" (NIV)appears in 4QXII" Minor Prophets as כי שנתה שלח. Martin Abegg, Peter Flint and Eugene Ulrich, The Dead Sea Scrolls Bible: The Oldest Known Bible for the First Time in English (San Francisco: Harper, 1999), interpret this as "For if you hate and divorce," in a negative mode; however, Brin, "Divorce at Qumran," in Legal Texts, 231-44 at 234, interprets it differently, in a positive mode: "for if you hate her send her away." The text of Tg. Ps.-J., ארי אם סנית לה פטרה, and the LXx translation could also be interpreted in both ways. B. Giț. 9ob records a dispute between two Amoraim about how to interpret this same enigmatic verse. Brin, who interprets it positively, asserts at 231 that "divorce was recognized as a legitimate phenomenon in Qumran." Tal Ilan, "Women in Qumran and the Dead Sea Scrolls," in The Oxford Handbook of the Dead Sea Scrolls (ed. Timothy H. Lim and John J. Collins; Oxford: Oxford University Press, 2010) 123-47 at 127, comments on Brin's thesis that "Whether he is right or not is hard to decide." I consider that the enigmatic text 
some attempt to justify it by means of a logical consideration, as is usually the case in the Qumran writings when a rule has no explicit biblical support and as we find in CD IV-V with respect to the prohibition on marrying two women and on marrying one's niece. We observe that 11 Q19 LVII:19, which implicitly prohibits divorce on the part of the king by decreeing that the king's wife must remain with him all her life, does not mention a general prohibition on divorce, which would have conflicted with the biblical rule that permits it. The command to the king to keep his only wife all her lifetime is a specific rule relevant only to the king, and has no explicit or implicit association with the rules relevant to other Israelites. ${ }^{79}$ The king/prince must live with one wife as long as she lives, and divorce is forbidden to him, as it is to the High Priest to whom, as I propose, he is compared in 11Q19, and who cannot marry a divorcée or a widow.

\subsubsection{Shemesh's Theory: Sexual Intercourse between a Man and an Unmarried Woman Is Equivalent to Marriage}

Shemesh ${ }^{80}$ theorizes that according to Qumran law, "any sexual intercourse between a man and an unmarried woman creates a marital bond regardless of whether or not this was the couple's intent." Therefore, the reason that $4 \mathrm{Q}_{271}$ $\left(4 \mathrm{QD}^{\mathrm{f}}\right)$ 3:13 prohibits marrying an unmarried or widowed woman if she has had intercourse with a man in her home is that she thereby became legally married to that man; since Qumran does not recognize a separation by divorce, marrying another man, Shemesh argues, would then be adultery. I believe that $4 Q_{271}$ is a recommendation not to bring into the community a promiscuous woman who is unfit to ensure the high standard of morality required for men and women alike - or even a prohibition on doing so-not an extension to all Israelites of the biblical prohibition upon the priests against marrying a

in Mal 2:16 does not constitute hard evidence either for or against divorce at Qumran, particularly to affirm that the prophet contradicts Deuteronomy. I have therefore not cited it in support of my thesis, which is built and substantiated on other arguments.

Philip R. Davies, Behind the Essenes: History and Ideology in the Dead Sea Scrolls (Atlanta, GA: Scholars Press, 1987), at 75 similarly states that ${ }_{11}$ 19 LVII is part of the "Torah of the King," and has no association with the CD rule, the subject of our inquiry. Brin, "Divorce at Qumran," 239-40 argues that 11Q19 LXVI:11, decreeing that the seducer cannot divorce the seduced girl all his life, attests "that divorce was known and permitted under ordinary circumstances." A similar evidence is offered by 4Q159 (4QOrdina) 2-4+8:9-10 with respect to the slanderer, who cannot ever divorce his wife.

8o Aharon Shemesh. "4Q271.3: A Key to Sectarian Matrimonial Law," JJs 49/2 (1998) 244-263 at $247-8$. 
prostitute, as Shemesh suggests. ${ }^{81}$ In fact, all the exhortations addressed in this lemma (4Q271 Frag. 3) concern the avoidance of immoral acts, and would not generate grave consequences for disobeying them, rather than transgressions of rules that provoke severe punishments. According to Shemesh, however, marrying an unbetrothed woman who had casual sexual intercourse would be deemed adultery. Schiffman, commenting on v. 8, which exhorts the father to disclose to the bridegroom his daughter's blemishes, emphasizes that "no penalty be assessed against the bride or her father" if he fails to do so. ${ }^{82}$ The father's obligation is the first rule of the lemma, indicating the overall advisory character of its various admonitions, in contrast to Shemesh's perception of them as apodictic commands.

Tברית הקודש The explicit details of the rule "Let no man bring [a woman into the ho]ly [covenant?]" (partly reconstructed) in 4Q271 (4QD $)$ 3:10-11 indicate that this is a particular ordinance for members of the community, not a general rule applicable to all Israelites, if indeed it would be deemed adultery, as Shemesh asserts. This rule, however, seems to me a precaution to ensure a high moral standard for both men and women in the community, and it is enforced by the Controller as good counsel within the ambit of his authority, as we read in CD XIII:16-18: "(the) overseer who is in the camp, and he shall do [ ] marries a woman and [ ] counsel and so to a divorced man and he shall inst[ruct ] ] in the love of mercy." The widow who has sexual intercourse is not therefore considered a married woman, for whom marriage is then prohibited as adultery or as an extension to all Israelites of the priestly prohibition on marrying a prostitute (Lev 21:14), as Schiffman suggests. ${ }^{83}$ Moreover, if such a temporary liaison were considered a wedding, all Israelites would be forbidden to marry prostitutes; yet Lev 21:3 prohibits this only for priests. The rules of Lev 21 apply to priests only, and the Qumran texts attempt to maintain distinctions of rank between priests and Israelites, particularly with respect to restricting intermarriage. The decree in $4 \mathrm{Q} 396\left(4 \mathrm{QMMT}^{\mathrm{c}}\right) \mathrm{IV}: 4-11$ that a priest may not marry an Israelite woman is a classic example of the difference between the holy Israelites and the Most Holy priests; Schiffman's suggestion that this decree extends Lev 21, equating Israelites with priests, does not seem compatible with Qumran's distinct theology. Shemesh's argument that divorce was not recognized in Qumran, relying on $4 \mathrm{Q}_{271}$, is therefore not convincing.

81 A similar dictum in b. Git. $90 \mathrm{a}+\mathrm{b}$ counsels a man to divorce his wife for shameful behaviour מצוה מן התורה לגרשה, and b. Git. 89a records a dispute as to when a man should divorce his wife for such behaviour.

82 Schiffman, "Laws Pertaining to Women" $547-569$ at 563 .

83 Ibid., 565 . 
On the other hand, since according to Shemesh, Qumran law deems that the physical sexual intercourse creates a marital bond, the same principle applies conversely, he argues, after one partner's death; the permanent physiological separation utterly rescinds any prior relationship between them. Consequently, he conjectures that the biblical prohibition of sexual intercourse with one's father's wife does not apply after the father's death. Shemesh substantiates his viewpoint by means of an apparently odd dictum in Jub. 33:15-16: "to Reuben was granted life and forgiveness after he had lain with his father's concubine, and to her also though she had a husband, and her husband Jacob, his father, was still alive." ${ }^{84}$ From the phrase "his father... was still alive," Shemesh-in common with Michael Segal—deduces implicitly that according to Jubilees a son may have intercourse with his father's widow. ${ }^{85} \mathrm{He}$ assumes that Jubilees and Qumran had an identical viewpoint on the theory that the physical act engenders a legal association, and conversely its dissolution rescinds it. I dispute this assumption: I doubt that the Torah-centered Qumran scholars would have accepted such a halakhah, which does not correspond to the simple meaning of the relevant text (Lev 18:7-8). We must instead interpret these verses as relating to cases occurring after one's father's death, as the rabbis declare (m. Sanh. 7:4) and as is evident from the text, which gives no hint of any limitation on this command; such intercourse, that is, as long as the father lives, would in any case (without this specific rule) be prohibited, either because she would be a married woman or, if divorced, because, as Shemesh declares (although I dispute it), Qumran rules do not permit the remarriage of a divorcée, as long as her husband is alive. Further, the preceding v. 6, which introduces the sexual prohibitions, reads: "No one is to approach any close relative to have sexual relations. I am the LORD." The verse stresses the character of the close relationship between the partners, irrespective of whether the relative is living or not. In the one case in which such a distinction is madethat of the prohibition to marry one's wife's sister- - Lev 18:18 specifies the distinction explicitly as long as she lives; we may therefore assume ex silentio that death does not affect the other prohibitions.

I also doubt whether Jubilees' author indeed intended to pronounce a halakhah permitting sexual intercourse with one's father's widow. Jubilees does not contain halakhot contradicting scriptural law, and its interpretations of scriptural commands are stringent, rather than promoting leniency. The fact

\footnotetext{
84 Translation: The Apocrypha and Pseudepigrapha of the Old Testament (trans. R.H. Charles; Oxford: Clarendon Press, 1913).

85 Michael Segal, The Book of Jubilees: Rewritten Bible, Redaction, Ideology and Theology (Leiden: Brill, 2007).
} 
that Jubilees accuses Reuben of lying with his father's concubine, considered sinful because his father was still alive, does not absolutely imply that it would be permitted after the father's death. The principle that if something specific is prohibited, anything else is permitted, cannot be applied indiscriminately and without due consideration. A mental lapse by the author of Jubilees, failing to anticipate a possible misinterpretation — such as indeed, in my opinion, Shemesh's deduction - cannot be excluded, but I think that another consideration may explain this apparently odd detail in Jubilees. Reuben slept with Bilhah-Jacob's concubine, not his wife ${ }^{86}$ - and it is plausible that Jubilees distinguishes between a concubine, who is not prohibited to a son after his father's death, and אשת אביך his wife, who is prohibited forever. We observe that there was no concern about Adonijah's marrying Abishag the Shunammite, a concubine of his father King David, after the latter's death (1 Kgs 2:15-25); his execution, by Solomon's order, was rather for fear that he might try to regain the kingship, as is evident from Solomon's reply to his mother Bathsheba (1 Kgs 2:22). Although 1 Kgs 1:4 declares that David did not have intercourse with Abishag, her legal status was that of a concubine, and therefore Adonjiah could marry her. At any rate, even if Qumran indeed interpreted Jubilees' dictum as Segal asserts, we have no evidence that Qumran acknowledged all of Jubilees' halakhot, as Shemesh assumes. Though many Qumran halakhot concur with those of Jubilees, Qumran texts never mention Jubilees as a source of or support for their halakhic interpretations or decisions. For more on this particular issue see Heger, Challenges, $224-25 \cdot{ }^{87}$ Although I wrote there, relying on scholarly opinions, that Qumran did not recognize the validity of divorce, I have now changed my mind, after delving myself into the study of this issue.

\subsubsection{Vered Noam's Theory That Qumran Followed the Rule of the Ancient Halakah, Prohibiting Divorce Altogether}

Vered Noam understands בחייהם in CD IV:20-V:1 as prohibiting divorce altogether. ${ }^{88}$ She supports her reading by arguing that an early halakhah in Sifre Num piska 7 permitted divorce only after a "judicial procedure," and hence Qumran's halakhah followed the rule of the generally acknowledged early

86 The author discerns between her concubine status in relation to Jacob, and his status of husband in relation to her.

87 See further motives for disputing Shemesh's theory in Heger, "Qumranic Marriage Prohibitions" at $448-51$.

88 Vered Noam, "Divorce in Qumran in Light of Early Halakhah," JJS LVI:2 (2005): 206-23 at 206-7. 
halakhah. I entirely disagree with her interpretation of the Sifre, quoted by her, as evidence for her assertion, but since the contention of her thesis requires a lengthy and complex debate of exclusively rabbinic writings, I do not consider it appropriate to be part of this book. I will therefore limit myself at this stage to indicating that Friedman published an extensive study disputing Noam's thesis. ${ }^{89}$ I agree to his conclusion, which coincides with my interpretation of the relevant rabbinic writings; I present, however, different arguments in my analysis, to be published in due course.

In conclusion, in light of the earlier analyses and discussion of the relevant texts and my arguments against contending scholarly opinions, I believe we can reasonably postulate that divorce was not prohibited in Qumran and that divorced people could remarry, as Scripture, Qumran's fons et origo, explicitly declares.

89 Shamma Friedman, "Sorting Out the Wages of Adultery: Execution, Ordeal or Divorce," in Shoshanat Yaakov:Jewish and Iranian Studies in Honor of Yaakov Elman (ed. Shai Secunda and Steven Fine; Leiden: Brill, 2012) 77-109. 